Journal of Bangladesh Academy of Sciences, Vol. 34, No. 1, 9-14, 2010

\title{
REDUCTION OF COD AND pH OF TEXTILE INDUSTRIAL EFFLUENTS BY AQUATIC MACROPHYTES AND ALGAE
}

\author{
R. ROY, A. N. M. FAKHRUDDIN*, R. KHATUN ${ }^{1}$ AND M. S. ISLAM ${ }^{2}$ \\ Department of Environmental Sciences, Jahangirnagar University, Savar, Dhaka-1342, \\ Bangladesh
}

\begin{abstract}
Effluents samples collected from post discharge of equalization tanks of local composite textile mills of Saver were treated with aquatic macrophytes, algae and their combination. They were found to be effective for the reduction of chemical oxygen demand (COD) and pH. Sixty nine per cent of COD was reduced with the combination treatment of Nostoc, Eichhornia crassipes and Pistia stratiotes. With the combination treatment of Nostoc and E. crassipes reduced 65 per cent COD in glass containers. $\mathrm{pH}$ was reduced from 11.2 to 8.6. Between earthen and glass containers, glass container was found to be more effective.
\end{abstract}

Key words: Industrial effluents, COD, pH, Aquatic macrophytes, Algae

\section{INTRODUCTION}

Textile industrial sector is one of the most important and largest industrial sectors of Bangladesh. Seventy eight per cent of the total export earning come from textile and textile related goods. This sector provides 4.5 million jobs and contribute $13 \%$ to GDP (BTMA 2007).

Textile industries consume large volume of water and chemical for wet process of textile. The quantities and characteristics of effluent discharged vary from mill to mill depending on the water consumption and the average daily product (Saha 2007). One of the burning problems of our industrial society is the high consumption of water. Many approaches have been taken to reduce water consumption, but better to recycle wastewater into high quality water (Schroder et al. 2007).

Dyeing and finishing are two important steps in the textile industry. These steps involve the dyeing of man-made or natural fibres to the desired permanent colors and processing of the fibers into final commercial products. In the dyeing and finishing processes a considerable amount of wastewater, effluent is generated, which is very toxic and contain strong colour, a large amount of suspended solids, a highly fluctuating $\mathrm{pH}$, high temperature, COD, BOD etc. (Garnham 1965). Because of these characteristics, treatment of textile wastewater is an essential requirement before it is being disposed to natural water system (Kabir et al. 2002).

* Author for correspondence, <a.fakhruddin2@mail.dcu.ie>.

${ }^{1}$ Biological Research Division, Bangladesh Council of Scientific and Industrial Research, Dhaka- 1205, Bangladesh.

${ }^{2}$ Analytical Research Division, Bangladesh Council of Scientific and Industrial Research, Dhaka- 1205, Bangladesh. 
Attempts were made to treat textile effluents with biological means and to observe the effects of differently made culture vessels on the reduction of COD and $\mathrm{pH}$ during biological treatments.

\section{MATERIALS AND METHODS}

Effluent was collected from H.R. Textiles Mills Ltd., located at Kornapara in Savar upazilla Dhaka, Bangladesh, and situated at N 23 49' 31" and E 90 $15^{\prime} 28^{\prime \prime}$. The industry has equalizer tank which collects effluents and mix them well. Effluent samples were collected in afternoon because at that time one cycle is completed. Samples were collected during February, May and July, 2008.

Aquatic macrophytes were collected from the Jahangirnagar University campus lakes which had no connection with any textile effluent. The aquatic macrophytes were preserved in the artificial pond in Biological Research Division of BCSIR using tap water only at normal temperature. Inoculum of Nostoc was obtained from the Biological Research Division, BCSIR, Dhaka.

The $\mathrm{pH}$ of water was determined by using a glass electrode $\mathrm{pH}$ meter. COD was determined according to Closed Reflux, Titrimetric method (Greenberg et al. 1998).

Textile effluent sample was taken on big plastic bowl and let it settled for three days. After then precipitate was separated from liquid effluent and the latter was used for aquatic macrophytes and algal treatment.

In the first experiment three types of aquatic macrophytes were used separately. Two types of containers, earthen and glass jar were used for each type of aquatic macrophyte. Every container was washed with tap water and then rinsed with effluent. Two liters of effluent was taken in each container. For $S$. cuculata and $P$. stratiotes treatment, eight-ten fresh plants were used. But for $N$. indicum treatment two fresh plants were used. The body and root part of the plants were washed with tap water to remove sediment and other impurities. Plants in each type of treatment were changed at every two days interval and continued for seven days including settlement. Control treatments included effluent in respective containers without any aquatic macrophytes.

In the second experiment for algal treatment three types of containers were used, earthen container, conical flask and glass jar. Every container was treated as mentioned above. Two liters of effluent were taken in earthen container and in glass jar and $500 \mathrm{ml}$ were taken in conical flask. In earthen container and in glass jar $400 \mathrm{~g}$ and in conical flask $20 \mathrm{~g}$ Nostoc were used. After an interval of two to three hours the effluent was stirred with a stick to maintain equal distribution of alga in the effluent. Control was also taken for each kind of treatment. Effluent with algal treatment was kept for four days.

In the third experiment after settlement the effluent was taken for Nostoc and E. crassipes treatments. For this two types of containers were used, earthen container and 
glass jar. Two liters of effluent were taken in each earthen container and glass jar. Washed two plants of E. crassipes and $77 \mathrm{~g}$ of Nostoc were used. After two days interval E. crassipes was changed and again replaced by fresh plant, but Nostoc was not changed. Effluent remained under this treatment for four days.

\section{RESULTS AND DISCUSSION}

Results of the reduction of COD of effluents using aquatic macrophytes, alga and their combination treatments are shown in Table 1. In the first set of experiment, the initial COD was $720.0 \mathrm{mg} / \mathrm{l}$. After treatment with P. stratiotes, $N$. indicum, S. cuculata, Nostoc and combination of Nostoc and E. crassipes COD was reduced to 300, 391.6, 389.6, 337.6 and $300 \mathrm{mg} / \mathrm{l}$, respectively in earthen container. In the second set of experiment, the initial COD was $652.8 \mathrm{mg} / \mathrm{l}$. After treatment with $P$. stratiotes, $N$. indicum, S. cuculata, Nostoc and combination of Nostoc and E. crassipes COD was reduced to 306, 244.8, 346.8, 448.8 and $244.4 \mathrm{mg} / \mathrm{l}$, respectively in glass jar. In the third set of experiment, the initial COD was $800 \mathrm{mg} / \mathrm{l}$. After treatment with $P$. stratiotes, $N$. indicum, S. cuculata, Nostoc, combination of Nostoc and E. crassipes and combination of Nostoc, E. crassipes and P. stratiotes COD was reduced to 270.6, 312, 353.6, 530.0, 280.8 and $250.68 \mathrm{mg} / \mathrm{l}$, respectively in glass container. In all three sets of experiments, highest amount of reduction was observed by the combination treatment of Nostoc and $E$. crassipes and/or $P$. stratiotes.

COD was reduced to $61 \%$ in coagulation method (alum + lime + ferric chloride) from textile effluent (Rajraiday and Markendey 1998) and the adsorption filtration method reduced COD to $40-75 \%$ on column configuration (Ahmed 2007). The COD removal rate with microflora (biological method) was 69\% (Rajraiday and Markendey 1998). The elements which are needed in coagulation system and adsorption filtration method are very expensive and complex to use than the aquatic macrophytes and algae used in this study. Aquatic macrophytes and algae are available in our country. So, aquatic macrophytes and algae combination method is more effective and less costly than coagulation and adsorption filtration method. Wolverton and McDonald (1976) observed that $E$. crassipes reduced the BOD of polluted waters. The study of Sooknah and Wilkie (2004) evaluated the potential of E. crassipes, P. stratiotes and Hydrocotyle umbellata in improving the water quality in terms of nutrient, COD, solids and salinity reductions. They reported the reduction in nutrients and COD with water hyacinth exhibiting the highest rates. For water hyacinth, total Kjeldahl nitrogen was reduced by $91.7 \%$, ammonium by $99.6 \%$, total phosphorus by $98.5 \%$, and soluble reactive phosphorus by $96.5 \%$ in 31-day-batch growth. A polyculture of the three plant species in $1: 1$ diluted exhibited the next best performance.

Results of the reductions of $\mathrm{pH}$ of textile industrial effluents using aquatic macrophytes and Nostoc and their combinations are shown in Table 1. In the first set of 
experiments, the initial $\mathrm{pH}$ was 9.6. After treatment with $P$. stratiotes, $N$. indicum, $S$. cuculata, Nostoc and combination of Nostoc and E. crassipes $\mathrm{pH}$ reduced to 7.47, 7.13, $7.44,7.72$, and 8.16, respectively in earthen container. In the second set of experiments, the initial $\mathrm{pH}$ was 10.7. After treatment with P. stratiotes, $N$. indicum, S. cuculata, Nostoc and combination of Nostoc and E. crassipes pH reduced to 9.0, 8.7, 9.3, 9.2, and 8.4, respectively in glass container. In the third set of experiment, the initial $\mathrm{pH}$ was 11.2. After treatment with P. stratiotes, N. indicum, S. cuculata, Nostoc and combination Nostoc and E. crassipes, combination of Nostoc, E. crassipes and P. stratiotes $\mathrm{pH}$ reduced to $8.9,9.0,9.6,9.2,8.6,8.8$, respectively in glass container. In all the experiments highest amount of reduction was observed with Nostoc and E. crassipes in combination treatment.

Mahmood et al. (2005) reported that biological treatment with E. crassipes showed a considerable reduction in the conductivity and $\mathrm{pH}$ of the wastewater, the $\mathrm{pH}$ was reduced to nearly neutral in all cases. They interpreted that the reduction in $\mathrm{pH}$ could be due to absorption of pollutants by plant. The reduction in $\mathrm{pH}$ favored microbial action to degrade BOD and COD in the wastewater.

Results presented in Table 1 also show the effect of containers. Plastic, earthen and glass containers were used with $S$. cuculata treatment. $\mathrm{pH}$ was reduced by 15.10, 22.5 and $14.28 \%$ with plastic, earthen and glass containers, respectively and COD was reduced to 86.67, 45.88 and $55.8 \%$ with plastic, earthen and glass containers, respectively. Earthen container was most effective for $\mathrm{pH}$ and plastic container for COD treatment of textile effluent with $S$. cuculata. Earthen and glass containers were used in P. stratiotes treatment. $\mathrm{pH}$ was reduced by 22.18 and $20.53 \%$ with earthen and glass containers, respectively and COD was reduced 58.33 and $66.2 \%$ with earthen and glass containers, respectively. Earthen container was most effective for $\mathrm{pH}$ and glass container for COD treatment of textile effluent with $P$. stratiotes.

Results presented in Table 1 showed earthen container was most effective for $\mathrm{pH}$ and glass container for COD treatment of textile effluent with $N$. indicum, and conical flask was most effective for $\mathrm{pH}$ and COD treatment with Nostoc. But for the combination treatment of Nostoc and E. crassipes treatment glass container was found to be most effective for $\mathrm{pH}$ and COD treatment.

In COD treatment higher amount reduction was observed in combination treatment and glass container is more effective for COD treatment than earthen container.

In this study $\mathrm{pH}$ was reduced by $25.73 \%$ with $N$. indicum treatment in earthen container but in glass container amount of $\mathrm{pH}$ reduction was $23.21 \%$ with Nostoc and $E$. crassipes treatment. The $\mathrm{pH}$ removal rate with microflora (biological method) was reported 16.19\% (Rajvaiday and Markendey 1998). Since the variation of $\mathrm{pH}$ with 
Table 1. Reduction of COD and pH of textile industrial effluents by aquatic macrophytes and algae in different containers.

\begin{tabular}{|c|c|c|c|c|c|c|c|c|}
\hline \multirow[t]{2}{*}{ Expt. } & \multirow{2}{*}{$\begin{array}{l}\text { Biological } \\
\text { Treatment } \\
\end{array}$} & \multirow[t]{2}{*}{ Container } & \multicolumn{3}{|c|}{$\mathrm{pH}$} & \multicolumn{3}{|c|}{$\mathrm{COD}\left(\mathrm{mgO}_{2} / \mathrm{l}\right)$} \\
\hline & & & Initial & $\begin{array}{l}\text { After } \\
\text { 7days } \\
\end{array}$ & $\begin{array}{c}\% \\
\text { removal } \\
\end{array}$ & Initial & $\begin{array}{l}\text { After } \\
\text { 7days } \\
\end{array}$ & $\begin{array}{c}\% \\
\text { removal } \\
\end{array}$ \\
\hline \multirow{5}{*}{$\begin{array}{c}\text { First } \\
\text { set }\end{array}$} & Control & Earthen & 9.6 & 8.80 & 8.33 & 720 & 650.0 & 9.72 \\
\hline & S. cuculata & " & 9.6 & 7.44 & 22.50 & 720 & 389.6 & 45.88 \\
\hline & P. stratiotes & $"$ & 9.6 & 7.47 & 22.18 & 720 & 300.0 & 58.33 \\
\hline & N. indicum & " & 9.6 & 7.13 & 25.73 & 720 & 391.6 & 45.61 \\
\hline & $\begin{array}{l}\text { Nostoc and } \\
\text { E. crassipes }\end{array}$ & $"$ & 9.6 & 8.16 & 15.00 & 720 & 300.0 & 58.33 \\
\hline \multirow{6}{*}{$\begin{array}{l}\text { Second } \\
\text { set }\end{array}$} & Nostoc & $"$ & 9.6 & 7.72 & 20.00 & 720 & 337.6 & 53.11 \\
\hline & Nostoc & Conical flask & 9.6 & 7.90 & 18.00 & 720 & 311.2 & 56.77 \\
\hline & Control & Glass jar & 10.7 & 10.0 & 6.54 & 652.8 & 620.28 & 4.98 \\
\hline & S. cuculata & " & 10.7 & 9.3 & 13.08 & 652.8 & 346.80 & 46.87 \\
\hline & P. stratiotes & " & 10.7 & 9.0 & 15.88 & 652.8 & 306.00 & 53.12 \\
\hline & $N$. indicum & $"$ & 10.7 & 8.7 & 18.69 & 652.8 & 244.80 & 62.50 \\
\hline \multirow{9}{*}{$\begin{array}{c}\text { Third } \\
\text { set }\end{array}$} & $\begin{array}{l}\text { Nostoc and } \\
\text { E. crassipes }\end{array}$ & " & 10.7 & 8.4 & 21.49 & 652.8 & 244.40 & 62.56 \\
\hline & Nostoc & " & 10.7 & 9.2 & 14.01 & 652.8 & 448.80 & 31.25 \\
\hline & Control & Glass jar & 11.2 & 9.9 & 11.60 & 800 & 707.20 & 11.60 \\
\hline & S. cuculata & " & 11.2 & 9.6 & 14.28 & 800 & 353.60 & 55.80 \\
\hline & P. stratiotes & $"$ & 11.2 & 8.9 & 20.53 & 800 & 270.40 & 66.20 \\
\hline & $N$. indicum & $"$ & 11.2 & 9.0 & 19.64 & 800 & 312.00 & 61.00 \\
\hline & $\begin{array}{l}\text { Nostoc and } \\
\text { E. crassipes }\end{array}$ & $"$ & 11.2 & 8.6 & 23.21 & 800 & 280.80 & 64.90 \\
\hline & Nostoc & $"$ & 11.2 & 9.2 & 17.85 & 800 & 530.00 & 33.75 \\
\hline & $\begin{array}{l}\text { Nostoc, } \\
\text { E. crassipes } \\
\text { and } \\
\text { P. stratiotes }\end{array}$ & " & 11.2 & 8.8 & 21.42 & 800 & 250.68 & 68.66 \\
\hline
\end{tabular}

respect to distance in lake where the textile effluent of Dhaka Export Processing Zone released is very low and the $\mathrm{pH}$ value was found 9.1 (Ahmed 2007), so in glass container Nostoc and E. crassipes treatment reduce $\mathrm{pH}$ from 11.2 to 8.6 which is quite helpful for fish culture.

\section{CONCLUSIONS}

Combination treatment of aquatic macrophytes and an alga were found to be effective for the reduction of COD. Sixty nine per cent of COD was reduced with the combination treatment of Nostoc, E. crassipes and P. stratiotes and 65\% of COD was reduced with the combination treatment of Nostoc and E. crassipes in glass container. In glass container Nostoc and E. crassipes treatment reduced $\mathrm{pH}$ from 11.2 to 8.6. Treatment in glass container was more effective than earthen container for reduction of $\mathrm{pH}$ and COD. 


\section{ACKNOWLEDGEMENT}

Authors are grateful to the authorities of H.R. Textiles Mills Ltd., Savar, Dhaka, Bangladesh for giving permission to collect effluent samples from equalizer tank for the present investigation.

\section{REFERENCES}

Ahmed T. 2007. Characterization of textile effluent from selected industries in DEPZ and their treatment by adsorption-filtration process. M. Sc. Thesis, Department of Environmental Sciences, Jahangirnagar University.

Bangladesh Textile Mills Association (BTMA), 2007. Annual Report, 14-35.

Greenberg A. E., L. S. Clesceri and A. D. Eaton. 1998. Standard method for the examination of water and wastewater. $20^{\text {th }}$ Edition. Eds. American Public Health Association, American Water Works Association \& Water Environment Federation.

Gurnham F. C., (Ed.) 1965. Industrial wastewater control. Academic Press, New York.

Kabir E. S., M. Kabir, S. M. Islam, C. M. Mia, N. Begum, D. A. Chowdhury, M. S. Sultana, and S. M. Rahman. 2002. Assessment of effluent quality of Dhaka export processing zone with special emphasis to the textile and dying industries. Jahangirnagar Uni. J. Sci. 25: 137-138.

Mahmood Q., P. Zheng, E. Islam, Y. Hayat, M. J. Hassan, G. Jilani and R. C. Jin. 2005. Lab scale studies on water hyacinth (Eichhornia crassipes Marts Solms) for biotreatment of textile wastewater. Caspian J. Env. Sci. 3: 83-88.

Rajvaiday N. and K. D. Markendey. 1998. Advances in Environmental science and technology, Vol. 8: Treatment of textile industrial effluent. A. P. H. Publishing Corporation, New Delhi, 6: $51-68$ \& 163-172.

Saha R.. 2007. Impact of the effluents of textile dying industries on the water quality of D.N.D. embankment area, Narayanganj. M. Sc. Thesis, Jahangirnagar University.

Schröder P., J. Navarro-aviñó, H. Azaizeh, A. G. Goldhirsh, S. Digregorio, T. Komives, G. Langergraber, A. Lenz, E. Maestri, A. R. Memon, A. Ranalli, L. Sebastiani, S. Smrcek, T. Vanek, S. Vuilleumier and F. Wissing. 2007. Using Phytoremediation Technologies to Upgrade Waste Water Treatment in Europe. Env. Sci. Pollut. Res. 14: 490- 497.

Sooknah R. D. and A. C. Wilkie. 2004. Nutrient removal by floating aquatic macrophytes cultured in anaerobically digested flushed dairy manure wastewater. Ecological Engineering 22: 27-42.

Wolverton B. C. and R. C. Mcdonald. 1976. Don’t waste waterweeds. New Scientist, 71: 318-320. 